УДК 338.24 .01

\title{
ТЕОРЕТИЧНІ ОСНОВИ ФОРМУВАННЯ ЦИФРОВОЇ СТРАТЕГІЇ ПІДПРИЕМСТВ
}

\section{THEORETICAL BASES OF THE DIGITAL STRATEGY OF ENTERPRISES FORMATION}

\author{
Панчук Анастасія Сергіївна \\ кандидат економічних наук, доцент, \\ Харківський національний економічний університет \\ імені Семена Кузнеця \\ ORCID: https://orcid.org/0000-0002-9386-2499 \\ Малькова Карина Олександрівна \\ здобувач освіти другого (магістерського) рівня, \\ Харківський національний економічний університет \\ імені Семена Кузнеця \\ ORCID: https://orcid.org/0000-0001-7741-3557
}

Panchuk Anastasiia, Malkova Karyna

Simon Kuznets Kharkiv National University of Economics

\begin{abstract}
Стаття присвячена визначенню особливостей стратегічного планування діяльності підприємств в умовах цифровізації бізнесу та визначенню місця цифрової стратегії у загальній системі стратегічного управління. Авторами проаналізовано останні публікації, в яких наведено теоретичні основи стратегічного планування цифровізації бізнесу. В статті розглянуто еволюцію терміну «цифрова стратегія» починаючи із переходу від впровадження стратегії інформаційних технологій до інтеграції цифрової стратегії в існуючу класифікацію стратегій за трьома рівнями управління: корпоративним, бізнес та функціональним. Вивчення еволюції визначень поняття «цифрова стратегія» свідчить, що в залежності від контексту вченими даний термін розглядається: як процес вибору інформаційних технологій, для використання в управлінні бізнесом, як елемент копоративної стратегії, як одна з бізнес-стратегій підприємства, як складова маркетингової або комунікаційної стратегії. За результатами проведених досліджень, доведено, що запровадження підприємствами стратегічного планування в умовах цифровізації створить умови для формування конкурентних переваг, максимального задоволення споживачів, адаптації до нових реалій ведення бізнесу підприємства та координацією діяльності різних підрозділів на стратегічному, тактичному та оперативному рівнях управління. Авторами статті визначено, що з урахуванням специфрічних умов ведення бізнесу в умовах цифрової економіки, визначення терміну «цифрова стратегія» потребує доопрацювання, з точки зору необхідності визначення місця цифрової стратегії підприємства в цій ієрархії. Узагальнення існуючих підходів, думок вітчизняних та зарубіжних вчених щодо змісту та визначення поняття «цифрова стратегія» підприємства, дозволило запропонувати власний підхід. Таким чином, пропонується визначати цифррову стратегію підприємства як процес координації цифровізації ключових ссрер діяльності підприємства: бізнес-моделей, клієнтського досвіду, операційних процесів із загальним стратегічним напрямом, 3 метою створення (підвищення) цінності продуктів, послуг та рішень у цифровій економіці.
\end{abstract}

Ключові слова: управління, бізнес, цифрова стратегія, стратегічне планування, цифрова економіка.

Статья посвящена определению особенностей стратегического планирования деятельности предприятий в условиях цифровизации бизнеса и места цифровой стратегии в общей системе стратегического управления. Авторами проанализированы последние публикации, в которых приведены теоретические основы стратегического планирования цисровизации бизнеса. В статье рассмотрена эволюция развития термина «цифровая стратегия», начиная с подхода предполагающего внедрение стратегии инорормационных технологий до интеграции цифровой стратегии в существующую классификацию стратегий по трем уровням управления: корпоративному, бизнес и функциональному. Изучение эволюции определений понятия «цифровая стратегия» свидетельствует, что в зависимости от контекста, учеными данный термин рассматривается: как процесс выбора информационных технологий, для использования в управлении бизнесом, как элемент копоративной стратегии, как одна из бизнес-стратегий предприятия, как составляющая маркетинговой или коммуникационной стратегии. Исходя из результатов проведенных исследований доказано, что внедрение 
предприятиями стратегического планирования в условиях цифровизации создаст условия для формирования конкурентных преимуществ, максимального удовлетворения потребителей, адаптации к новым реалиям ведения бизнеса предприятия и координации деятельности различных подразделений на стратегическом, тактическом и оперативном уровнях управления. Авторами статьи определено, что с учетом специсических условий ведения бизнеса в условиях цифровой экономики, определение термина «цифровая стратегия» требует доработки с точки зрения необходимости определения места цифровой стратегии предприятия в этой иерархии. Обобщение существующих подходов, мнений отечественных и зарубежных ученых относительно содержания и определения понятия «цифровая стратегия» предприятия позволило предложить свой подход. Таким образом, предлагается определять цифровую стратегию предприятия как процесс координации циф-ровизации ключевых сорер деятельности предприятия: бизнес-моделей, клиентского опыта, операционных процессов с общим стратегическим направлением с целью создания (повышения) ценности продуктов, услуг и решений в цифровой экономике.

Ключевые слова: управление, бизнес, цифровая стратегия, стратегическое планирование, цифровая экономика.

The article is devoted to determining the features of strategic planning of enterprises in the context of business digitalization and the place of digital strategy in the overall system of strategic management. The authors analyze the latest publications, which provide the theoretical foundations of strategic planning for business digitalization. The article examines the evolution of the term "digital strategy", from the approach of implementing an information technology strategy to the integration of digital strategy into the existing classification of strategies at three levels of government: corporate, business and functional. The study of the evolution of definitions of "digital strategy" shows that, depending on the context, scientists consider this term: as a process of choosing information technology for use in business management, as part of corporate strategy, as one of business strategies, as a component of marketing or communication strategy. Based on the results of research, it is proved that the introduction of strategic planning by enterprises in digital conditions will create conditions for competitive advantage, maximum customer satisfaction, adaptation to new realities of business and coordination of various departments at strategic, tactical and operational levels. The authors of the article determined that given the specific conditions of doing business in a digital economy, the definition of the term "digital strategy" requires refinement in terms of the need to determine the place of digital strategy of the enterprise in this hierarchy. The generalization of the existing approaches, opinions of domestic and foreign scientists concerning the maintenance and definition of the concept of "digital strategy" of the enterprise allowed to offer the approach. Thus, it is proposed to define the digital strategy of the enterprise as a process of coordinating the digitization of key areas of the enterprise: business models, customer experience, operational processes with a common strategic direction to create (increase) the value of products, services and solutions in the digital economy.

Keywords: management, business, digital strategy, strategic planning, digital economy

Постановка проблеми. В умовах четвертої хвилі технологічної революціії важливу роль в розвитку країн відіграє цифрова економіка, головним драйвером якої $є$ інфрормація та знання, а також шляхи доступу до них.

На думку експертів, цифррова економіка - це не окрема галузь, а віртуальне середовище, яке доповнює фізичну реальність. Основними перевагами цифрової економіки є підвищення доступності ізольованих раніше користувачів до певних товарів та послуг, зниження транзакційних витрат, підвищення ефрективності і конкурентоспроможності цілих ринкових галузей. Слід зазначити, що на думку більшості науковців, цифрова економіка - це інноваційна динамічна економіка, що базується на активному впровадженні інновацій та інфрормаційно-комунікаційних технологій у всі види економічної діяльності та ссрери життєдіяльності суспільства, що дозволяє підвищити ефрективність та конкурентоспроможність окремих підприємств, економіки та рівень життя населення [1-4].

У зазначених умовах, не викликає сумніву, необхідність розроблення нових підходів до ведення бізнесу, управління підприємствами, здійснення маркетингової діяльності. Стратегічне планування діяльності підприємств, в тому числі, не втрачає своєї актуальності, але має, певні особливості в умовах цифррової економіки.

Аналіз останніх досліджень і публікацій. Дослідженню питань пов'язаних із управлінням бізнесом та стратегічним плануванням діяльності підприємств в умовах цифрових транссрормацій займаються провідні консалтингові агенства, такі як McKinsey, BCG (Boston Consulting Group), науково-дослідні центри таких університетів як MIT (Massachusetts Institute of Technology) та Harvard Business School. Зарубіжними вченими А. Ліпсмейєр, А. Кюхн, Р. Йоппен та Р. Думітреску [5] досліджено історичний контекст розробки цифрових стратегій підприємств, Дж. Морхаус та А. Caqpфер [6] визначено цифрові стратегії 3 точки зору двох підходів: як вид комунікаційної та як одну з бізнес стратегій. Вітчизняні вчені М. Кіржецька та Ю. Кіржецький [7] визначають різновиди цифрових стратегій в залежності від розміру та типу підприємства. 
Виділення невирішених раніше частин загальної проблеми. Проведені дослідження свідчать про те, що теоретико-методологічне забезпечення цифровізації управлінських процесів залишається недостатньо обґрунтованим, що обумовлює актуальність теми дослідження.

Формулювання цілей статті. Метою статті $€$ аналіз теоретичних підходів до визначення терміну «цифррова стратегія» та вироблення, на цій основі, власного визначення, відповідно до сучасних умов.

Виклад основного матеріалу дослідження. Підходи до визначення поняття «цифровізація», майже, не викликають різночитань серед фрахівців та експертів у галузі дослідження. Так, у більшості джерел, цифровізація (digitalization) розглядається як соціально-економічна трансорормація, ініційована масовим використанням та засвоєнням цифрових технологій, а саме технологій створення, обробки, обміну та передачі інформації [8, с. 3].

Агресивні цифррові трансформації всіх галузей економіки від публічного адміністрування до медичного обслуговування, бізнес-процесів підприємств від маркетингової діяльності до виробництва продукції, призводять до активної дискусії в науковій літературі щодо сутності та методів розробки цифрових стратегій.

Більшість авторів схильні вважати, що для забезпечення довгострокової конкурентоспроможності підприємства і адаптації до нових реалій ведення бізнесу, цифровізацію необхідно розглядати із позицій стратегічного підходу, але цифрова трансформація підприємства не $є$ класичним стратегічним проєктом чи програмою, яку можна легко ініціювати та виконувати в запланований проміжок часу [9]. Крім того, необхідно розуміти цисррову трансфрормацію процесу стратегічного управління підприємством як динамічний, безперервний процес. Отже, цифрову стратегію, що координує цисррові перетворення у підприємстві, необхідно розглядати як центральний та інтегрований компонент стратегічного управління. Натомість, відсутність обґрунтованої цифрової стратегії неминуче призведе до втрати конкурентних переваг, реалізації тільки ізольованих, маломасштабних проєктів в короткостроковій перспективі без використання будь-яких ефректів синергії. Не зважаючи на це, розробка цифрової стратегії являє собою досить серйозну проблему для більшості підприємств. Зокрема, новизна та складність циорровізації стратегічного рівня управління викликають труднощі для багатьох фрахівців підприємств. Так, за даними представленими Міністерством цифррової трансформації України переважна більшість - 89\% представників бізнесу вважають, що корпоративна стратегія їх компанії містить лише цілі циоррової трансформації, а майже половина директорів підприємств оцінили рівень свого бізнесу як помірний, а біля $10 \%$ опитаних вважають, що рівень цифррової трансформації підприємств $€$ низьким та дуже низьким.

Отже, існуюча класифрікація стратегій за трьома рівнями управління: корпоративним, бізнес та фрункціональним, потребує доопрацювання 3 точки зору необхідності визначення місця цифррової стратегії підприємства в цій ієрархії.

Доцільним є аналіз еволюційного розвитку поняття «цисррова стратегія», на рисунку 1 представлено основні його етапи.

Впровадження терміну стратегія підприємства в бізнес-літературу в середині 20-го століття відбувалося переважно через в контексті теорії рішення/ігор. Значно пізніше, розвиток інорормаційних технологій, поява перших персональних компьютерів призвели до обговорення стратегічного планування IT-систем, було започатковано IT-стратегії, компанією IBM було розроблено «Планування бізнес-систем» [10], де було розглянуто основи планування та розробки стратегій інформаційних технологій підприємства, але все ще зазначені стратегії розглядались окремо від бізнес-стратегій підприємства. На початку 1990-х в діяльність підприємств активно впроваджувалась «Модель трикутника», розроблена М. Ерлом [11], що була одним із перших підходів до вирівнювання IT-стратегії з бізнес-стратегіями.

Згодом, розробкою моделі Хендрікса-Венкатрана [12] було закладено основу для інтеграції IT-стратегій в загальну ієрархію стратегій підприємства. Передбачалось, що інсрормаційна стратегія стає однією зі стратегій на функціональному рівні. За рахунок розвитку та більш активного використання ІКТ-технологій у діяльності підприємств у 2010 році С. Мітас та Г. С. Лукас вводять поняття «цифрова бізнес стратегія» [13], що передбачає її інтеграцію в бізнес-стратегії підприємства.

Починаючи 3 того часу наукова дискусія стосовно визначення терміну «цисрова стратегія» та ії місця в системі стратегічного управління підприємством триває в науковій літературі.

Ряд науковців пояснюють, що цифррова стратегія - це процес оцисррування ролей 
1960-ті pp. виокремлення поняття стратегї̈ в бізнес літературі

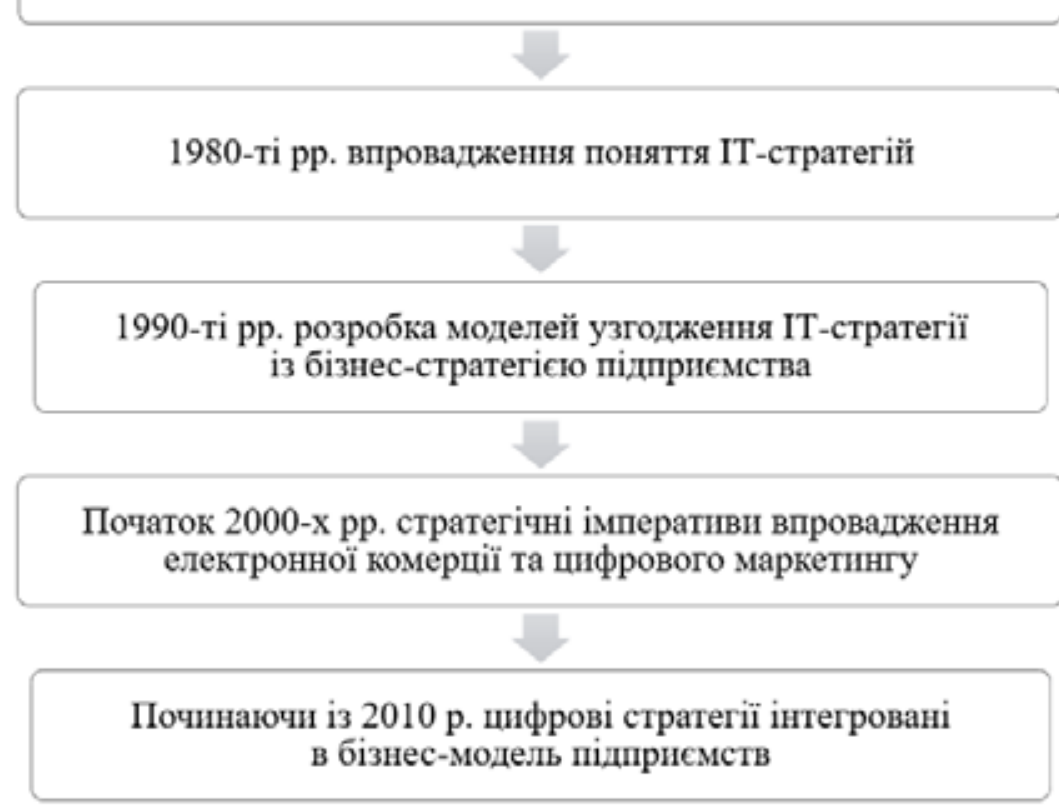

Рис. 1. Еволюція поняття «цифрова стратегія»

Джерело: власна розробка авторів

та обов'язків у підприємстві чи організації. 3 такого розуміння цифррова стратегія $€$ похідною від інформаційних технологій (IT) та інфрормаційних систем (IC) і $€$ способом модернізації діяльності підприємства за допомогою цифрровізації. Оцифррування включає інфрраструктуру, а також програмне забезпечення та додатки, які можуть бути використані для виробництва цисррових даних, що можуть, також, визначати організаційні рішення керівництва.

Можна погодитись із визначенням консалтингового агенства Accenture, яке стверджує, що цифррова стратегія шукає способи використання технологій для трансформації діяльності, а отже, і бізнесу, тоді як ІТ-стратегія спрямована на транссормацію технологій ізольовано від решти бізнесу [14].

Такі автори як В. С. Куйбіда О. В. Карпенко В. В. Наместнік, вважають, що цифррова стратегія зосереджується на використанні технологій для підвищення ефективності бізнесу, незалежно від того, чи означає це створення нових продуктів або переосмислення поточних процесів та визначають циоррову стратегію - як процес вибору інформаційних технологій, для використання/впровадження яких буде виділено фрінансування. За такий підхід, актуальність розробки цисррової стратегії постає в період, коли підприємства завершують почат- ковий етап інвестування у цифррові технології і виникає потреба в подальшому плануванні [15].

С. Метт, Т. Хесс та А. Бенліан зазначають, що цисррова стратегія визначає бажані майбутні можливості бізнесу на основі інтеграції та використання нових цифррових технологій для досягнення бажаного майбутнього стану підприємства [16].

Фахівці консалтингової компанії Bain\& Company визначають цифррові стратегії як стратегії цифровізації і цифрової трансформаціїі, що передбачать застосування цифрових технологій для зміни бізнес-моделей та створення конкурентного потенціалу підприємства [17].

Деякі науковці дотримуються точки зору, з якої цифрова стратегія стає частиною корпоративної або бізнес-стратегії підприємства. А. Бхарадвай та співавтори визначили, що циоррова стратегія бізнесу $є$ стратегією, яка ссрормована та реалізується через використання цифрових ресурсів для створення диференційних значень та консолідована із корпоративною стратегією підприємства [18].

Дослідження місця циоррової стратегії у корпоративній стратегії великого бізнесу І. Себастьяном показало, що цифрова стратегія $€$ однією із корпоративних стратегій, яка трансформує цифровий рівень бізнес-стратегії на фрункціональні стратегії підприємства [19]. 
Ґрунтовні дослідження А. Ліпсмейєр, А. Кюхн, Р. Йоппен та Р. Думітреску [5] дозволили авторам зробити висновки, що цифрова стратегія описує загальне бачення компанії в контексті цифровізації, включаючи стратегічні заходи щодо її досягнення. Це визначає конкретну, коротко-, середньо- та довгострокову цияровізацію, цілі та ініціативи в контексті продуктів, послуг і створення цінностей, а також для організації та культури підприємства.

У працях О. Воскобоєвої та О. Ромащенко визначено, що цифрова стратегія - це стратегія перетворення фрірми на цифрову, в якій цифровий зв'язок забезпечує взаємодію бізнес-організації зі своїми клієнтами, індивідуалізовані й персоналізовані пропозиції продуктів/послуг, прийняття рішень та реалізацію основних бізнес-срункцій на основі даних, під впливом змін у зовнішньому та внутрішньому середовищі фрірми [20]

Для підприємств малого бізнесу цифрова стратегія стає бізнес-стратегією та реалізується через інструменти цифррового маркетингу; діджиталізації бізнес-процесів; присутності в Інтернеті; е-commerce; управління бізнес-гнучкістю [7].

Частина авторів стверджує, що цифрова стратегія повинна генеруватись на фрункціональному рівні управління, так Маріам Х. Ісмаїл, Мохамед Хатер, Мохамед Закі вважають, що розроблення цифрової стратегії компаній великого чи середнього бізнесу потребує стратегічних рішень у кількох ключових сорерах, які будуть фрормуватися на рівні операційної стратегії через інкорпорування циоррової стратегії у бізнес-модель, технології компанії та просування продукту, що надаватиме можливості конкурувати на ринках та на фрункціональному рівні у сорері управлінських, організаційних, моделі структурних рішень та операційному вимірі стратегічних рішень для створення конкурентних переваг бізнесу [21].

Значна кількість фрахівців погоджуються із тим, що цифрова стратегія - це частина загальної маркетингової стратегії розвитку компанії, оскільки диджитал сам по собі не може бути ізольований від загальних маркетингової бази, наприклад клієнтської подорожі в офрлайн-середовищі, варіантів комунікації цінності продукту, цінової політики та unit-економіки та іншого.

Дослідники компаніії Netology [22] визначають цифрову стратегію як маркетинговий план, ціль якого полягає у загальному розвитку та перетворенні бізнесу, популяризації продукту або бренду. Для реалізації поставле- них завдань проводяться дослідження ринку, аудиторії, конкурентів, виявляються власні конкурентні переваги, відбираються відповідні цифррові канали та конкретні інструменти, використовуються актуальні технології.

Цифрова стратегія часто характеризується застосуванням нових технологій в існуючій ділової активності для задоволення нових потреб споживачів, підприємства та ринку управління клієнтським досвідом за допомогою цифрових технологій.

Частина визначень орієнтовані на стратегічну комунікацію та ґрунтуються на розумінні того, що цисррова стратегія виникла зі швидкого зростання цифррових комунікаційних інструментів, платформ і можливостей. За такий підхід, цифрова стратегія визначається як частина загальної комунікаційної стратегії підприємства, яка включає цисррові та традиційні стратегії, що служать для досягнення цілей організації за допомогою маркетингу, реклами або зв'язків з громадськістю.

Проведені дослідження теоретичних аспектів цисррової стратегії дозволили зробити узагальнення підходів до визначення цього терміну (табл. 1).

Узагальнюючи теоретичні підходи до визначення терміну «цифррова стратегія» та беручи до уваги ті сорери та фрункціональні області, яких, за думкою науковців та фрахівців, стосується ії фрормування, доцільно погодитись із твердженням які визначають цифрову транссрормацію як перетворення трьох ключових областей підприємства: клієнтського досвіду, операційних процесів та бізнес-моделей.

За думкою авторів, важливим доповненням до існуючих визначень $€$ включення до змісту цифррової стратегії аспектів створення та донесення цінності продуктів, послуг та рішень в умовах цисррової економіки.

Висновки. Таким чином, пропонується визначати цифрову стратегію підприємства як процес координації цифровізації ключових сорер діяльності підприємства: бізнес-моделей, клієнтського досвіду, операційних процесів із загальним стратегічним напрямом, 3 метою створення (підвищення) цінності продуктів, послуг та рішень у цифровій економіці.

Консалтингова компанія McKinsey зазначає, що цисррова стратегія підприємств дає змогу адаптуватися до цифррових змін, що відбуваються поза компанією, а також всередині неї. Враховуючи шалений темп цих змін, така стратегія повинна йти в ногу з темпами цифррових технологій і забезпечувати можливості для перших, оскільки її переглядають, повто- 
Таблиця 1

Узагальнення існуючих підходів до визначення цифрової стратегії

\begin{tabular}{|c|c|c|}
\hline $\begin{array}{c}\text { Характеристика } \\
\text { підходу }\end{array}$ & Визначення & Автори \\
\hline $\begin{array}{l}\text { Впровадження } \\
\text { інорормаційних } \\
\text { технологій } \\
\text { в діяльність } \\
\text { підприємства }\end{array}$ & $\begin{array}{l}\text { Цифрова стратегія визначає бажані майбутні } \\
\text { можливості бізнесу на основі інтеграції та } \\
\text { використання нових цифрових технологій для } \\
\text { досягнення бажаного майбутнього стану підприємства }\end{array}$ & $\begin{array}{l}\text { Метт С., } \\
\text { Хесс Т. } \\
\text { та Бенліан А. }\end{array}$ \\
\hline $\begin{array}{l}\text { Консолідація } \\
\text { цифрової } \\
\text { стратегії } 3 \\
\text { корпоративною } \\
\text { стратегією } \\
\end{array}$ & $\begin{array}{l}\text { Цифрова стратегія є частиною корпоративної стратегії } \\
\text { та інкорпорується в операційну й функціональні } \\
\text { стратегії підприємства. }\end{array}$ & $\begin{array}{l}\text { Воскобоєва О., } \\
\text { Ромащенко О., } \\
\text { Кіржецька М., } \\
\text { Кіржецький Ю. }\end{array}$ \\
\hline $\begin{array}{l}\text { Впровадження } \\
\text { на бізнес-рівні та } \\
\text { реалізація через } \\
\text { діджиталізацію } \\
\text { бізнес-процесів }\end{array}$ & $\begin{array}{l}\text { Цифррова стратегія - це стратегія перетворення фрірми } \\
\text { на цифрову, в якій цифровий зв'язок забезпечує } \\
\text { взаємодію бізнес-організації зі своїми клієнтами, } \\
\text { індивідуалізовані й персоналізовані пропозиції } \\
\text { продуктів/послуг, прийняття рішень та реалізацію } \\
\text { основних бізнес-функцій на основі даних, під впливом } \\
\text { змін у зовнішньому та внутрішньому середовищі фірми }\end{array}$ & $\begin{array}{l}\text { Ісмаїл М., } \\
\text { Кхатер М., } \\
\text { Закі М. }\end{array}$ \\
\hline $\begin{array}{l}\text { Генерація на } \\
\text { фрункціональному } \\
\text { рівні управління }\end{array}$ & $\begin{array}{l}\text { Цифррової стратегії компаній великого чи середнього } \\
\text { бізнесу потребує стратегічних рішень у кількох } \\
\text { ключових сферах, які будуть фрормуватися на рівні } \\
\text { операційної стратегії через інкорпорування цифрової } \\
\text { стратегії у бізнес-модель, технології компанії та } \\
\text { просування продукту, що надаватиме можливості } \\
\text { конкурувати на ринках та на фуунціональному } \\
\text { рівні у сфері управлінських, організаційних, моделі } \\
\text { структурних рішень та операційному вимірі }\end{array}$ & $\begin{array}{l}\text { Вестермана Дж., } \\
\text { Боннет В., } \\
\text { МакАфрі, А. }\end{array}$ \\
\hline $\begin{array}{l}\text { Частина } \\
\text { комунікаційної } \\
\text { стратегії } \\
\text { підприємства }\end{array}$ & $\begin{array}{l}\text { Цифррова стратегія визначається як частина загальної } \\
\text { комунікаційної стратегії підприємства, яка включає } \\
\text { цифррові та традиційні стратегії, що служать для } \\
\text { досягнення цілей організації за допомогою маркетингу, } \\
\text { реклами або зв'язків з громадськістю }\end{array}$ & $\begin{array}{l}\text { Хіт Р., } \\
\text { Йохансен В., } \\
\text { Морхаус Дж., } \\
\text { Caфpqpep А. }\end{array}$ \\
\hline
\end{tabular}

Джерело: власна розробка авторів на основі $[4 ; 5 ; 6 ; 7 ; 20]$

рюють і коригують набагато частіше, ніж стратегії в минулому.

Підсумовуючи результати досліджень, можна зробити висновок, що однією з ключових перешкод для циоррової транссрормації бізнесу - це відсутність цифрових стратегій, що координують ініціативи цифровізації відповідно до загального стратегічного напряму. Доцільним $€$ проведення провести подальших дослідження з метою детального аналізу особливостей фрормування цисррової стратегії вітчизняних підприємств.

\section{СПИСОК ВИКОРИСТАНИХ ДЖЕРЕЛ:}

1. Коляденко С. В. Цифровва економіка: передумови та етапи становлення в Україні і у світі. Економіка. Фінанси. Менеджмент. 2016. № 6. С. 106-107.

2. SME Competitiveness Outlook 2020 - COVID-19: the Great Lockdown and its Effects of Small Business. URL: https://www.intracen.org/uploadedFiles/intracenorg/Content/Publications/ITCSMECO2020.pdf (дата звернення: 21.01.2022).

3. Digital strategy in a time of crisis. 2021. URL: https://www.mckinsey.com/business-functions/mckinseydigital/ our-insights/digital-strategy-in-a-time-of-crisis (дата звернення: 28.12.2021).

4. Westerman, G., Bonnet, D. \& McAfee, A. The Nine Elements of Digital Transformation. MIT Sloan Management Review. 2014. URL: http://sloanreview.mit.edu/article/the-nine-elements-ofdigital-transformation (дата звернення: 28.12.2021).

5. Lipsmeier, A, Kühn, A, Joppen, R. \& Dumitrescu, R. Process for the development of a digital strategy. Procedia CIRP. 2020. № 88. P. 173-178.

6. Morehouse, J. \& Saffer, A. Digital Strategy. The International Encyclopedia of Strategic Communication. 2018. P. 1-7. 
7. Кіржецька, М., Кіржецький, Ю. Особливості цифрової стратегії підприємства залежно від розміру бізнесу. Галицький економічний вісник. 2020. № 5(66). С. 7-15.

8. Katz R. The Transformative Economic Impact of Digital Technology. The United Nations Commission on Science and Technology for Development. 2015. № 3. P. 2-11.

9. Mierzowski, S. Entwicklung einer Digitalisierungsstrategie - Digitale Transformation als Führungsaufgabe. Ausgabe. 2016. P. 42.

10. IBM. Business systems planning: information systems planning guide. Auflage IBM Corporation. 1984.

11. Earl, M J. Management strategies for information technology. Essex: Prentice Hall. 1989.

12. Henderson, J. C., Venkatraman, H. Strategic alignment: Leveraging information technology for transforming organizations. IBM Systems Journal, 1993. № 32. P. 472-484.

13. Mithas, S., Lucas, Jr H. C. What is Your Digital Business Strategy? IT Professional. 2010. № 12. P. 4-6.

14. Accenture agency. URL: https://www.accenture.com/us-en/about/strategy-index

15. Куйбіда В. С., Карпенко О. В. Наместнік В. В. Цифрове врядування в Україні: базові десрініції понятійно-категоріального апарату. Вісник Національної академії державного управління при Президентові України. Державне управління. 2018. № 1. С. 5-10.

16. Matt C., Hess T., Benlian A. Digital Transformation Strategies. Business \& Information Systems Engineering. 2014. № 57(5). P. 339-343.

17. Bain\&Company. Digital Strategy for a B2B World. 2017. URL: https://www.bain.com/insights/ digital-strategyfor-a-b2b-world (дата звернення: 28.12.2021).

18. Bharadwaj, A. et al. Digital Business Strategy: Toward a next generation of insights. 2013. № 37(2). P. 471-482.

19. Sebastian I. M. et al. How Big Old Companies Navigate Digital Transformation. MIS Quarterly Executive. 2017. № 16(3). P. 197-213.

20. Воскобоєва О. В., Ромащенко О. С. Індекс цифровізації як основний фрактор розвитку цифрових технологій. Економіка. Менеджмент. Бізнес. 2018. № 4(26). С. 56-61.

21. Ismail, M., Khater, M., Zaki, M. Digital Business Transformation and Strategy: What Do We Know So Far? 2017. URL: https://cambridgeservicealliance.eng.cam.ac.uk/resources/Downloads/Monthly\%20Papers/2017Nov Paper_Mariam.pdf (дата звернення: 27.12.2021).

22. Netology. URL: https://netology.ru/glossariy/digital-strategiya (дата звернення: 27.12.2021).

\section{REFERENCES:}

1. Koliadenko, S. V. (2016) Tsyfrova ekonomika: peredumovy ta etapy stanovlennia v Ukraini i u sviti [Digital Economy: Rethinking Stages of Formation in Ukraine and the Retinue] Ekonomika. Finansy. Menedzhment (electronic journal), no. 6, pp. 106-107.

2. SME Competitiveness Outlook 2020 - COVID-19: the Great Lockdown and its Effects of Small Business. Retrieved from: https://www.intracen.org/uploadedFiles/intracenorg/Content/Publications/ITCSMECO2020.pdf

3. Digital strategy in a time of crisis (2021). Retrieved from: https://www.mckinsey.com/business-functions/mckinseydigital/our-insights/digital-strategy-in-a-time-of-crisis

4. Westerman, G., Bonnet, D. \& McAfee, A. (2014) The Nine Elements of Digital Transformation. MIT Sloan Management Review. Retrieved from: http://sloanreview.mit.edu/article/the-nine-elements-ofdigital-transformation

5. Lipsmeier, A., Kühn, A., Joppen, R. \& Dumitrescu, R. (2020) Process for the development of a digital strategy. Procedia CIRP, no. 88, pp. 173-178.

6. Morehouse, J. \& Saffer, A. (2018) Digital Strategy. The International Encyclopedia of Strategic Communication, pp. 1-7.

7. Kirzhetska, M. \& Kirzhetskyi, Yu. (2020) Osoblyvosti tsyfrovoi stratehii pidpryiemstva zalezhno vid rozmiru biznesu [Features of the digital business strategy]. Halytskyi ekonomichnyi visnyk (electronic journal), no. 5(66), pp. 7-15.

8. Katz R. (2015) The Transformative Economic Impact of Digital Technology. The United Nations Commission on Science and Technology for Development, no. 3, pp. 2-11.

9. Mierzowski, S. (2016) Entwicklung einer Digitalisierungsstrategie - Digitale Transformation als Führungsaufgabe. Ausgabe, pp. 42.

10. IBM (1984) Business systems planning: information systems planning guide. Auflage IBM Corporation.

11. Earl, M. J. (1989) Management strategies for information technology. Essex: Prentice Hall.

12. Henderson, J. C. \& Venkatraman, H. (1993) Strategic alignment: Leveraging information technology for transforming organizations. IBM Systems Journal, no. 32, pp. 472-484. 
13. Mithas, S. \& Lucas, Jr H. C. (2010) What is Your Digital Business Strategy? IT Professional, no. 12, pp. 4-6. 14. Accenture agency. Retrieved from: https://www.accenture.com/us-en/about/strategy-index

15. Kuibida, V. S., Karpenko, O. V. \& Namestnik, V. V. (2018) Tsyfrove vriaduvannia v Ukraini: bazovi definitsii poniatiino-katehorialnoho aparatu [Digital implementation in Ukraine: basic definitions of the conceptual and categorical apparatus]. Visnyk Natsionalnoi akademii derzhavnoho upravlinnia pry Prezydentovi Ukrainy. Derzhavne upravlinnia, no. 1, pp. 5-10.

16. Matt C., Hess T. \& Benlian A. (2014) Digital Transformation Strategies. Business \& Information Systems Engineering, no. 57(5), pp. 339-343.

17. Bain\&Company (2017) Digital Strategy for a B2B World. Retrieved from: https://www.bain.com/insights/ digital-strategy-for-a-b2b-world

18. Bharadwaj, A. et al. (2013) Digital Business Strategy: Toward a next generation of insights, no. 37(2), pp. 471-482.

19. Sebastian I. M. et al. (2017) How Big Old Companies Navigate Digital Transformation. MIS Quarterly Executive, no. 16(3), pp. 197-213.

20. Voskoboieva, O. V. \& Romashchenko O. S. (2018) Indeks tsyfrovizatsii yak osnovnyi faktor rozvytku tsyfrovykh tekhnolohii [Digitization index as a major factor in the development of digital technologies]. Ekonomika. Menedzhment. Biznes (electronic journal), no. 4(26), pp. 56-61.

21. Ismail, M., Khater, M., Zaki, M. (2017) Digital Business Transformation and Strategy: What Do We Know So Far? Retrieved from: https://cambridgeservicealliance.eng.cam.ac.uk/resources/Downloads/Monthly\%20 Papers/2017NovPaper_Mariam.pdf

22. Netology. Retrieved from: https://netology.ru/glossariy/digital-strategiya 